\title{
Independent and inter-dependent immunoregulatory effects of NCF1 and NOS2 in experimental autoimmune encephalomyelitis
}

\author{
Jianghong Zhong ${ }^{1,2}$, Anthony C. Y. Yau ${ }^{1}$ and Rikard Holmdahl ${ }^{1 *}$
}

\begin{abstract}
Background: Increasing evidence has suggested that a single nucleotide polymorphism in the Ncf1 gene is associated with experimental autoimmune encephalomyelitis (EAE). However, the mechanisms of NCF1-induced immunoregulatory effects remain poorly understood. In this study, we focus on NCF1 deficiency-mediated effects on EAE in NOS2 dependent and independent ways.

Methods: To determine the effects of NCF1 and NOS2 during EAE development, we have established recombinant mouse strains deficient at NCF1 and/or NOS2 in a crossbreeding system. Different strains allow us to examine the entire course of the disease in the Nos2-null mice bearing a Ncf1 gene that encodes a mutated NCF1, deficient in triggering oxidative burst, after immunization with recombinant myelin oligodendrocyte glycoprotein (MOG) ${ }_{79-96}$ peptides. The peptide-induced innate and adaptive immune responses were analyzed by flow cytometry.

Results: NCF1-deficient mice developed a reduced susceptibility to EAE, whereas NCF1-NOS2 double-deficient mice developed an enhanced EAE, as compared with NOS2-deficient mice. Flow cytometry analyses show that double deficiencies resulted in an increase of neutrophils in the spleen, accompanied with higher release of interleukin-1 $\beta$ in neutrophils prior to EAE onset. The additional deficiency in NCF1 had no added effect on either interleukin-17 or interferon- $\gamma$ secretion of $T$ cells during the priming phase.
\end{abstract}

Conclusions: These studies show that NCF1 and NOS2 interact to regulate peptide-induced EAE.

Keywords: Experimental autoimmune encephalomyelitis, NCF1, NOS2, Interleukin-1ß, Neutrophil

\section{Background}

Polymorphism of $N c f 1$ is a major factor associated with autoimmune diseases, most likely through peroxide regulatory effects [1]. The neutrophil cytosol factor 1 (NCF1), also denoted $\mathrm{p} 47^{\mathrm{PHOX}}$, is a subunit of the NOX2 complex that converts oxygen into superoxide anion. Superoxide is converted to the peroxide but can

\footnotetext{
* Correspondence: rikard.holmdahl@ki.se

'Medical Inflammation Research, Department of Medical Biochemistry and Biophysics, Karolinska Institute, 17177 Stockholm, Sweden

Full list of author information is available at the end of the article
}

also react with nitric oxide $(\mathrm{NO})$ in an aqueous environment to yield peroxynitrite anion. Superoxide and peroxynitrite play a dual role in cellular and immune responses [2]. We previously showed that a single nucleotide polymorphism in Ncf1, resulting in loss-offunction amino acid substitution, led to an increased risk of developing arthritis [3, 4]. Superoxide defect by mutations in Ncf1 gene was subsequently shown to cause arthritis and lupus in mice [5, 6], and in humans [7-10].

The immunoregulatory roles of NCF1 have also been studied in experimental autoimmune encephalomyelitis 
(EAE), which is a widely accepted model to study multiple sclerosis (MS). In the rat model of EAE, the Ncf1 polymorphism leading to a reduction but not deficiency in superoxide production enhanced the disease severity $[11,12]$. In mice, a mutation in Ncf1 gene, leading to a nearly deficient superoxide production by the NOX2 complex, resulted in an enhanced EAE, in a model that was induced by recombinant rat myelin oligodendrocyte glycoprotein (MOG) ${ }_{1-125}$ protein; in contrast, immunization with a mouse $\mathrm{MOG}_{79-96}$ peptide led to reduced EAE [5]. Furthermore, a genetic knockout of Ncf1 has been reported to result in a complete protection of $\mathrm{MOG}_{35-55}$ peptide-induced EAE [13]. It has also been shown that the $\mathrm{H}-2 \mathrm{~b}$ mice that were deficient in NCF1 and CYBB subunits of the NOX2 complex were partially protected from EAE when induced by the rat $\mathrm{MOG}_{1-125}$ protein or mouse $\mathrm{MOG}_{35-55}$ peptide $[14,15]$.

Inducible nitric oxide synthase termed as NOS2 (alias iNOS) is known to release highly reactive molecules NO under inflammatory conditions [16]. Enhanced expression of NOS2 and peroxynitrite production were observed in mice with EAE $[17,18]$. The onset of EAE was delayed after treatment with peroxynitrite scavenger uric acid in SWXJ-14 mice [19], as well as after treatment of EAE with NO synthase (NOS) inhibitor L-NGnitroarginine methyl ester (L-NAME) in C57BL/6 mice [18]. EAE was reduced by using NOS inhibitor aminoguanidine (AG) in SJL mice [20]. In contrast, it was observed that AG treatment resulted in exacerbation of EAE in $P L / J$ mice [21]. Of interest, the administration of AG or L-NAME showed no effect on EAE in rats [22]. Recent studies have investigated the potential pathogenic mechanisms of NOS2, showing a regulatory role of NOS2 in EAE through peroxynitrite to modulate $\mathrm{T}$ cell differentiation in periphery, such as by an expansion of interferon-gamma (IFN- $\gamma$ )-positive cells [23] and the balance between interleukin-17A (IL-17A)-positive cells [24] and FOXP3-positive cells [25] in Nos2-deficient $C 57 B L / 6$ mice. In short, these studies of EAE have revealed diverse signaling events downstream of NOS2 deficiency and NOS inhibiting, and complex mechanisms could be mouse strain-dependent.

In this study, we conducted animal experiments by using NCF1- and NOS2-deficient mice of B6 genetic background and the model of $\mathrm{MOG}_{79-96}$ peptideinduced EAE [26]. Our results showed that although NCF1 deficiency leads to a reduced EAE in NOS2sufficient mice, NCF1 and NOS2 double-deficient mice displayed an enhanced EAE in comparison with NOS2deficient mice. Flow cytometry analysis of the spleen and lymph node cells shows the innate and adaptive immune responses to immunization. We found an increased number of neutrophils with enhanced IL-1 $\beta$ releases in double-deficient mice following immunization with
$\mathrm{MOG}_{79-96}$ peptides. Our data point to a possible mechanistic role conferred by NCF1 and NOS2 in enhancing the number of neutrophils that are available to protect against peptide-induced EAE.

\section{Materials and methods \\ Animals}

Founders of B6NQ (C57/B6N.Q/rhd) mice have been fully backcrossed and maintained by Holmdahl laboratory (rhd). A mutation in the Ncf1 gene (m1j) in the $B 6 N Q$ mice, designated as B6NQ.Ncf1 $1^{\mathrm{m} 1 \mathrm{j} / \mathrm{m} 1 \mathrm{j}}$, impairs the expression of the $N c f 1$ gene, thereby totally blocking the function of the NOX2 complex. NOS2-deficient mice $\left(B 6.129 P 2-N O S 2^{\mathrm{tm} 1 \mathrm{Lau} / \mathrm{J}}\right)$ were obtained from The Jackson Laboratory and were crossed to our B6NQ mice to get C57BL/6NJ.Q.Nos2 ${ }^{-/-}$mice $\left(\mathrm{Ncf1}^{+/+}{ }^{-N o s} 2^{-/-}\right)$with control $\mathrm{NcF1}^{+/+} . \mathrm{Nos}_{2}{ }^{+/}$littermates in the experiments here. $\mathrm{Ncf1}^{+/+}{ }^{\mathrm{Nos} 2^{-/-}}$mice were crossed with B6NQ.Ncf1 ${ }^{\mathrm{mlj} / \mathrm{mlj}}$ mice to generate the C57BL/

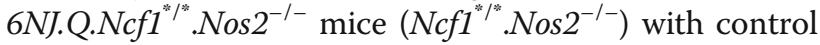

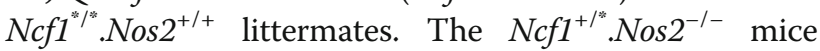
with a heterogeneous $N c f 1$ gene were intercrossed to generate $N c f 1^{\prime \prime / "}$.Nos $2^{-l-}$ mice with control $\mathrm{Ncf1}^{+/+}$.Nos $2^{-/-}$littermates. Screening for Ncf1 was performed by TaqMan real-time PCR [27]. The primers for Nos2 genotyping are as follows: 5' - ACA TGC AGA ATG AGT ACC GG-3' (common), 5' - TCA ACA TCT CCT GGT GGA AC-3' (wild type), 5' - AAT ATG CGA AGT GGA CCT CG-3' (mutant) [28]. All mice in this study expressed the MHC H2-Aq haplotype. Littermate male mice were used in our experiments, and the identity was blinded for the investigator. Mice were housed under specific pathogen-free conditions in individual ventilated cages with wood shaving bedding, a paper napkin as enrichment, and in a climate-controlled environment having a 12-h light/dark cycle. We have mixed experimental cages of 8- to 9-week-old homozygous littermates. Each adult mouse weighed approximately $25 \mathrm{~g}$. Experimental groups were randomized and distributed among mixed cages. The animal study protocols were approved by the Stockholm regional animal ethics committee, Sweden (N83/13).

\section{Antibodies}

The following antibodies were purchased from BioLegend, as CD45 (clone: 30-F11, PerCP/Cy5.5 or PECyanine7), CD11b (clone: M1/70, Pacific Blue), Ly6G (clone: 1A8, PerCP/Cy5.5), Ly-6C (clone: HK1.4, APC or Brilliant Violet 605TM), TNF- $\alpha$ (clone: MP6-XT22, PECyanine7), and IL-17A (clone: TC11-18H10.1, FITC, or APC). Antibodies for CD16/CD32 (clone: 2.4G2, purified), $\mathrm{CD} 3 \varepsilon$ (clone: 145-2C11, PerCP/Cy5.5, or PECyanine7), CD4 (clone: RM4-5, Pacific Blue, or PE), and IFN- $\gamma$ (clone: XMG1.2, APC) were purchased from BD 
Pharmingen. Antibodies for IL-1 $\beta$ (clone: 166931, FITC) were purchased from R\&D Systems. Antibodies for NCF1 (clone: D-10, FITC) were purchased from Santa Cruz Biotechnology. Antibodies for NOS2 (clone: CXNFT, PE-Cyanine7) were purchased from eBioscience. The usage of antibodies is according to the suggestions from the source companies, and the classical dilution ratio of the stock solution is 1:200 for flow cytometry staining.

\section{Induction and evaluation of EAE}

The mice were age-matched and immunized at the base of the tail with $25 \mu \mathrm{g}$ recombinant $\mathrm{MOG}_{79-96}$ peptides emulsified in Freund's complete adjuvant (CFA, BD Difco, Catalog No. 263810, Sweden). Three hundred nanograms of pertussis toxin from Bordetella pertussis (Sigma-Aldrich Co., Catalog No. P2980-.2MG, Sweden) in $100 \mu \mathrm{L}$ of phosphate-buffered saline (PBS, ThermoFisher, Cat. No. 14190-169, Sweden) was intravenously administrated at the day of immunization and $48 \mathrm{~h}$ later. $\mathrm{MOG}_{79-96}$ peptide corresponds to amino acids of the mouse sequence (GKVTLRIQNVRFSDEGGY) and was synthesized by Shafer-N, Copenhagen, with a purity of $>$ 97\%. The mice will not develop peptide-induced EAE without injection of pertussis toxin, according to the protocol. Clinical signs of EAE were assessed by using a standard scoring protocol [5, 26]. Disease progression was evaluated blindly by the same observer using a clinical scoring as follows: 0 , normal; 1 , tail weakness; 2 , tail paralysis, normal gait; 2.5 , tail paralysis, little affected gait; 3, tail paralysis, low back, and mild waddle; 3.5 , tail paralysis and low back, severe waddle; 4, tail paralysis, severe waddle, less sure footing; 4.5 , tail paralysis, severe waddle, falling and lost balance; 5 , tail paralysis and paralysis of one limb, crawling; 6, tail paralysis and paralysis of a pair of limbs, back is affected; and 7, tetra-paresis; 8, pre-morbid or deceased. The endpoint of the experiment is when the mice reach the EAE score of 7 . According to the clinical scoring protocol, the onset day is defined as the first day the mouse has shown the clinical symptom with a positive score.

\section{$\mathrm{T}$ cell recall assay}

At the time point indicated in the text and figures, the mouse with EAE was euthanized. Detailed time points for the use of $\mathrm{CO}_{2}$ euthanasia were day 10 to collect inguinal lymph node cells and day 14 to collect splenocytes post-immunization, respectively. Suspensions of single cells were used for ex vivo analysis. Cells were cultured with $\mathrm{MOG}_{79-96}$ peptides $(50 \mu \mathrm{g} / \mathrm{mL})$ for $24 \mathrm{~h}$ or $96 \mathrm{~h}$, and then the culture supernatant was collected to determine the level of cytokines and nitric oxide production. The concanavalin A (ConA, Sigma-Aldrich Co.,
CAS No. 11028-71-0, Sweden) (3 $\mu \mathrm{g} / \mathrm{mL})$ was used as the positive control during the recall assay.

\section{Nitrite/nitrate detection in medium}

The obtained cell culture supernatant samples were stored at $-80^{\circ} \mathrm{C}$ until analysis. A commercial nitric oxide $\left(\mathrm{NO}_{2} / \mathrm{NO}_{3}\right)$ research kit (Enzo Life Sciences, Inc., Catalog No. ADI-917-010, Sweden) was used to determine the level of nitric oxide in a microplate reader (Synergy 2; BioTek, Inc., VT, USA).

\section{L-NAME treatment}

Age-matched mice were administered intraperitoneally with $100 \mu \mathrm{L}$ volume of NG-nitro-L-arginine methyl ester (L-NAME) (Sigma-Aldrich Co., CAS No. 51298-62-5, Sweden) or PBS once per day for 19 or 20 days after immunization. L-NAME was dissolved into PBS. The dose of L-NAME was $4.3 \mathrm{mg} / 100 \mu \mathrm{L} /$ mouse/time, or $172 \mathrm{mg} / \mathrm{kg}$ body weight per time, $\mathrm{pH}$ 7.4.

\section{Cytometric beads array}

Cytokines levels in the splenic cell culture supernatant were measured by flow cytometry using BD cytometric bead array (CBA, BD Biosciences, Catalog No. 552364, Sweden) mouse soluble protein master buffer kit (IL-1 $\alpha$, GM-CSF, and TNF- $\alpha$ ) according to the manufacturer's instruction. Briefly, $1 \times 10^{6}$ spleen cells were collected from immunized mice, which were re-stimulated with $\mathrm{MOG}_{79-96}$ peptides $(50 \mu \mathrm{g} / \mathrm{mL})$ for $24 \mathrm{~h}$ at $37^{\circ} \mathrm{C}$.

\section{Flow cytometry}

Flow cytometry was performed on single-cell suspensions from lymph nodes and spleens. The cell density was counted by using Sysmex KX-21 N automated hematology analyzer (Sysmex Corporation, NY). The cell sample was stained with a LIVE/DEAD ${ }^{\oplus}$ fixable near-IR dead cell stain (ThermoFisher, Catalog No. L10119, Sweden). After an anti-mouse CD16/CD32 Fc block, extracellular antigens were stained $20 \mathrm{~min}$ at $4{ }^{\circ} \mathrm{C}$ in PBS with $1 \%$ fetal bovine serum (FBS, Gibco, ThermoFisher, Catalog No. 26140079, USA). To measure intracellular ROS/RNS, the staining of $3 \mu \mathrm{M}$ Dihydrorhodamine 123 (DHR 123, ThermoFisher, Catalog No. D23806, Sweden), or $5 \mu \mathrm{M}$ 6-carboxy-2',7'-dichlorodihydrofluorescein diacetate (DCF, ThermoFisher, Cat. No. C400, Sweden) was conducted respectively after cell surface markers staining, followed by stimulation of $100 \mathrm{ng} / \mathrm{mL}$ of phorbol 12-myristate 13-acetate (PMA, Sigma-Aldrich Co., CAS No. 16561-29-8, Sweden) alone or plus $1 \mu \mathrm{g}$ / $\mathrm{mL}$ of ionomycin (ThermoFisher, Catalog No. I24222, Sweden) for $30 \mathrm{~min}$. To detect the intracellular expression of cytokines, the cells were stimulated with $100 \mathrm{ng} /$ $\mathrm{mL}$ of PMA and $1 \mu \mathrm{g} / \mathrm{mL}$ of ionomycin in the presence of $5 \mu \mathrm{g} / \mathrm{mL}$ of brefeldin A (BFA, ThermoFisher, Catalog 
No. B7450, Sweden) for $4 \mathrm{~h}$ at a humidified $37^{\circ} \mathrm{C}, 5 \%$ $\mathrm{CO}_{2}$ incubator. The stock solutions of PMA, ionomycin, and BFA were prepared with dimethylsulfoxide (DMSO, Sigma-Aldrich Co., CAS No. 67-68-5, Sweden). For intracellular cytokine staining, cells were fixed and permeabilized using BD cytofix/cytoperm solution (BD Biosciences, Catalog No. 554714, Sweden). The workstation is managed by FACSDiva software version 8.0 (BD Biosciences), and the data were analyzed using the FlowJo software version 10.5.3 (TreeStar, Inc., OR).

\section{Statistics}

Statistical analyses were performed with Graph Prism software, version 8.2.1 (GraphPad Software, San Diego, USA). Unless otherwise stated, Mann-Whitney $U$ test was used to compare the means of two groups. All results are shown as mean \pm standard error of the mean. $p$ value $<0.05$ was considered as significant: ${ }^{*} p<0.05$, "** $p$ $<0.01,{ }^{* * * *} p<0.001$, and ${ }^{* * * * *} p<0.0001$.

\section{Results \\ Enhanced EAE is induced in mice deficient in NCF1 and NOS2}

To identify the role of NCF1 and NOS2 in the development of EAE, we have established appropriate mouse strains by crossing Ncf1-mutant and Nos2-null mice, followed by backcrossing to wild-type (B6NQ.Ncf1 ${ }^{+/+}$) mice and NCF1-deficient (B6NQ.Ncf1" $\left.{ }^{\prime \prime \prime}\right)$ mice. Previous data has shown that NCF1 deficiency can lead to reduced EAE in mice (B10Q.Ncf1/**) if immunized with $\mathrm{MOG}_{79-96}$ peptide [5]. In this study, we observed similarly that $N c f 1$-mutant mice $\left(N c f 1^{\prime / /} . N o s 2^{+/+}\right)$developed milder disease during the early phase of EAE, with a delayed disease onset (Fig. 1a). Based on oxidative burst products generated by the NCF1-NOX2 complex, it is difficult to determine the exact level of peroxynitrite among superoxide, NO, peroxynitrite, and hydrogen peroxide. However, the role of peroxynitrite can be studied by using NOS inhibitor L-NAME [29, 30]. L-NAME treatment results in a delayed onset of EAE (Additional file $1 \mathrm{a}$ and $1 \mathrm{~b}$ ). These results suggest that superoxide and peroxynitrite are downstream products of NCF1, promoting inflammation at the initial stage of peptide induced EAE.

We next determined the role of NCF1-derived superoxide in EAE, using NOS2-deficient mice with reduced capacity to form NO and peroxynitrite [29]. Figure 1b shows that double-deficient mice $\left(\mathrm{Ncfl}^{* /{ }^{*}}{ }^{\mathrm{N} N o s 2^{-/-}}\right.$) developed EAE with an earlier disease onset and a more severe disease during the early stage than their littermate controls $\left(\mathrm{NcFl}^{+/+} . \mathrm{Nos}^{-/-}\right)$. Another interesting finding was that NOS2-deficient mice developed a more severe disease during the chronic phase, regardless of NCF1 expression (Additional file 1c and 1d). Based on the data in Fig. 1a and b and Additional file 1c and 1d, the 2-way ANOVA test was performed among wild-type mice, NCF1-deficient mice, NOS2-deficient mice, and NCF1NOS2-deficient mice. The interaction $p$ values of the ANOVA tables for both mean severity and onset day are less than 0.01, reaching the statistical significance (Fig. 1c). Using Bonferroni's multiple comparisons test of mean severity to determine the significance of the interested pairwise comparison, we found that it is significant from $N c f 1^{* / *} . N o s 2^{+/+}$mice vs Ncf1/" ${ }^{* / N}$.Nos $2^{-/-}$mice with a $p$ value $<0.001$. In Bonferroni's multiple comparisons test of onset day, it is significant from $\mathrm{Ncfl}^{+/+} . \mathrm{Nos}_{2}{ }^{+/+}$ mice vs $N c f 1^{* / *}$.Nos $2^{+/+}$mice with a $p$ value $<0.05$. In summary, these results show a regulatory effect of NCF1 on EAE induction in NOS2-deficient mice (Table 1).

Results from in vivo analyses provide evidence that EAE is regulated by NCF1 and NOS and that NCF1 is protective during EAE induction. Additionally, a regulatory role is likely for NOS2 during EAE remission.

\section{T cell immune response to antigens is not regulated by NCF1 and NOS2 deficiencies}

To study redox mechanisms of enhanced EAE in double-deficient mice, we firstly examined adaptive immune responses to immunization. The previous study of NOS2 mice showed that inter-dependent regulation of NOX2 and NOS2 in IL-17-positive T cells was critical to enhanced diseases [24, 25]. Therefore, we determined the effect of oxidative burst on $\mathrm{T}$ cells characterized by production of IFN- $\gamma$ and IL-17 during EAE induction. At day 10 post immunization, we collected inguinal lymph nodes for flow cytometric analysis, using doubledeficient mice $\left(\mathrm{Ncf1}^{\prime \prime /}{ }^{*} \mathrm{Nos}^{-/-}\right)$that developed more severe EAE than their littermates $\left(\mathrm{Ncfl}^{+/+} . \mathrm{Nos}^{-/-}\right.$genotype) (Fig. 2a). We found that frequencies of neither IFN- $\gamma$ nor IL-17A-positive cells in NOS2-deficient CD4 $\mathrm{T}$ cells were influenced by NCF1 deficiency, upon restimulation ex vivo with PMA and ionomycin (Fig. 2b, c). In addition, we measured the level of cytokine production in cell cultures after re-stimulation ex vivo with $\mathrm{MOG}_{79-96}$ peptides. The levels of IFN- $\gamma$ and IL-17A after antigen recall stimulation were similar between the two

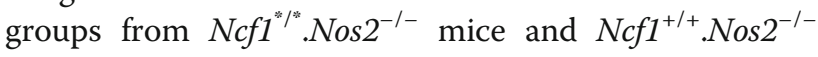
littermates (Fig. 2d).

In comparison with lymph nodes, spleens have a higher frequency of myeloid cells that express both NCF1 and NOS2. Therefore, we performed a recall assay on spleen cells from mice at day 14 postimmunization, when the disease was very severe (Additional file 2a). Although we observed a decrease in NO production from NOS2-deficient spleen cells stimulated ex vivo with ConA (Additional file 2b), there was no difference in IL-17A level between these groups (Additional file 2c and $2 \mathrm{~d}$ ). 
A
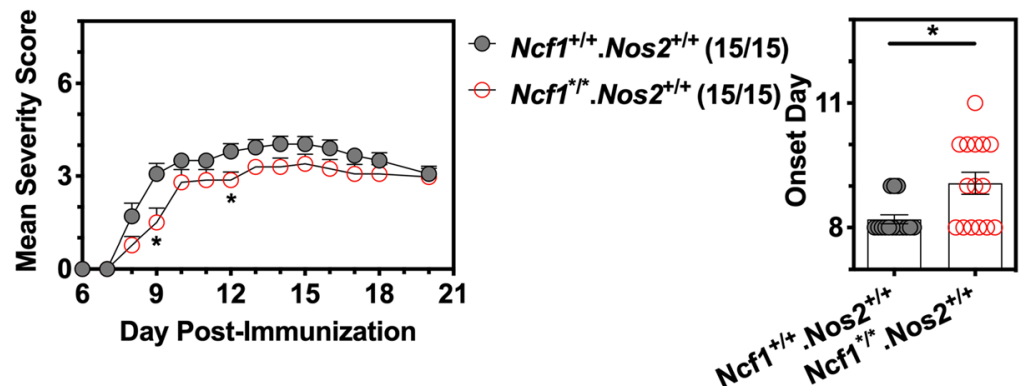

B
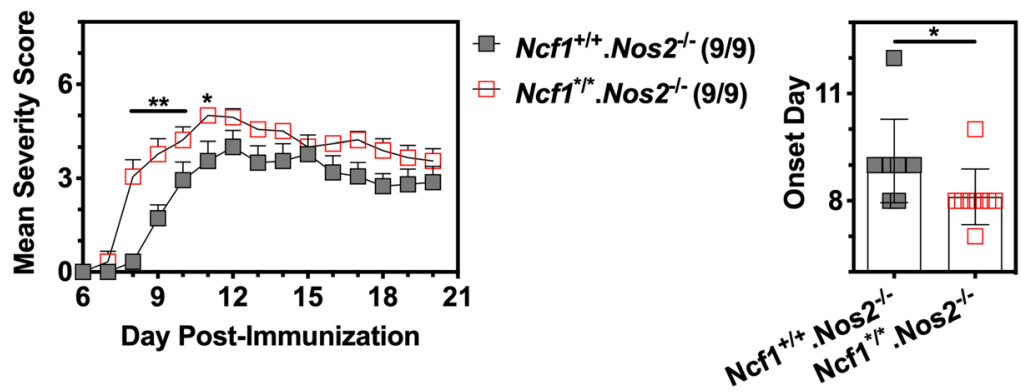

C

Two-way ANOVA, Interaction P value **
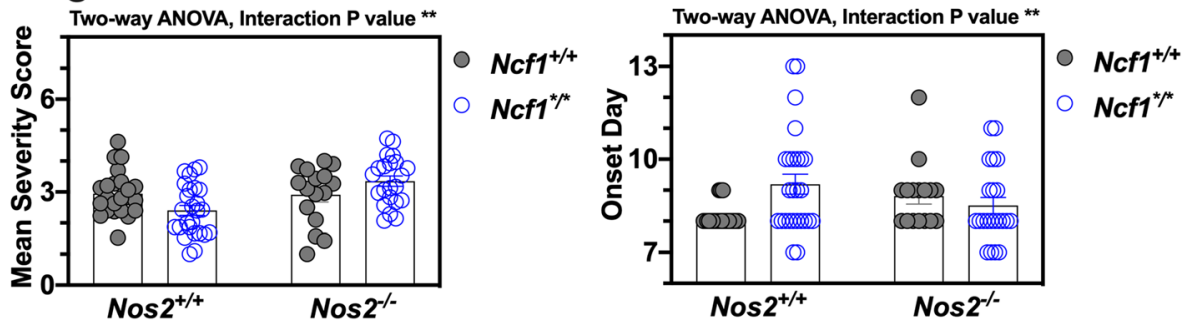

Fig. 1 Independent and inter-dependent effects of NCF1 and NOS2 play a dual role in EAE. a NCF1 deficiency slightly suppressed the severity and delayed the onset of EAE in mice with normal NOS2. b A combined NOS- and NCF1-deficient mice developed an enhanced EAE, together with early onset forms of the disease. In $\mathbf{a}$ and $\mathbf{b}$, the number of mice that developed EAE and the total number of mice in each group are stated in brackets. No mice died before the endpoint. ${ }^{*} p<0.05$ and ${ }^{* *} p<0.01$ as determined in $\mathbf{a}$ and $\mathbf{b}$ by the Mann-Whitney $U$ test. $\mathbf{c}$ the interaction $p$ values of the two-way ANOVA tables for both mean severity and onset day are less than 0.01 , reaching the statistical significance. In c, each sign stands for a mouse, and experimental mice of four strains were collected from $\mathbf{a}$ and $\mathbf{b}$ and Additional file 1c and 1d

Table 1 Descriptive statistics of the disease course across different mouse strains with EAE

\begin{tabular}{|c|c|c|c|c|}
\hline Target group & Control group & Acute EAE & Chronic EAE & Data source \\
\hline$\overline{\mathrm{NCfl}^{* / *} \cdot \mathrm{NoS}_{2}^{+/+}}$ & $\mathrm{Ncfl}^{+/+} . \mathrm{Nos}_{2}^{+/+}$ & $\downarrow$ & ns & Fig. 1a \\
\hline $\mathrm{Ncfl}^{* / *} \cdot \mathrm{Nos}^{-1-}$ & $\mathrm{Ncfl}^{+/+} \cdot \mathrm{Nos}^{-/-}$ & $\uparrow$ & ns & Fig. $1 b$ \\
\hline $\mathrm{NCFl}^{+/+} . \mathrm{NoS}^{-/-}$ & $\mathrm{NCFl}^{+/+} . \mathrm{Nos}^{+/+}$ & ns & $\uparrow$ & Additional file 1c \\
\hline $\mathrm{Ncfl}^{* / *} \cdot \mathrm{Nos}^{-/-}$ & $\mathrm{Ncfl}^{* / *} \cdot \mathrm{Nos}^{+/+}$ & ns & $\uparrow$ & Additional file $1 \mathrm{~d}$ \\
\hline $\mathrm{L}-\mathrm{NAME}+\mathrm{NCF1}^{+/+} . \mathrm{Nos}^{+/+}$ & $\mathrm{PBS}+\mathrm{Ncfl}^{+/+} \cdot \mathrm{Nos}^{+/+}$ & $\downarrow$ & ns & Additional file $1 \mathrm{a}$ \\
\hline L-NAME $+\mathrm{Ncfl}^{* / *} \cdot \mathrm{Nos}^{+/+}$ & $\mathrm{PBS}+\mathrm{Ncfl}^{* / *} \cdot \mathrm{Nos}^{+/+}$ & $\downarrow$ & ns & Additional file $1 \mathrm{~b}$ \\
\hline
\end{tabular}

Note: The day 14 post-immunization is used to distinguish between acute and chronic EAE. A down arrow stands for a reduced severity of EAE; an up arrow stands for an enhanced severity of EAE; ns stands for no statistical significance. The comparison between two groups was determined by the Mann-Whitney $U$ test 


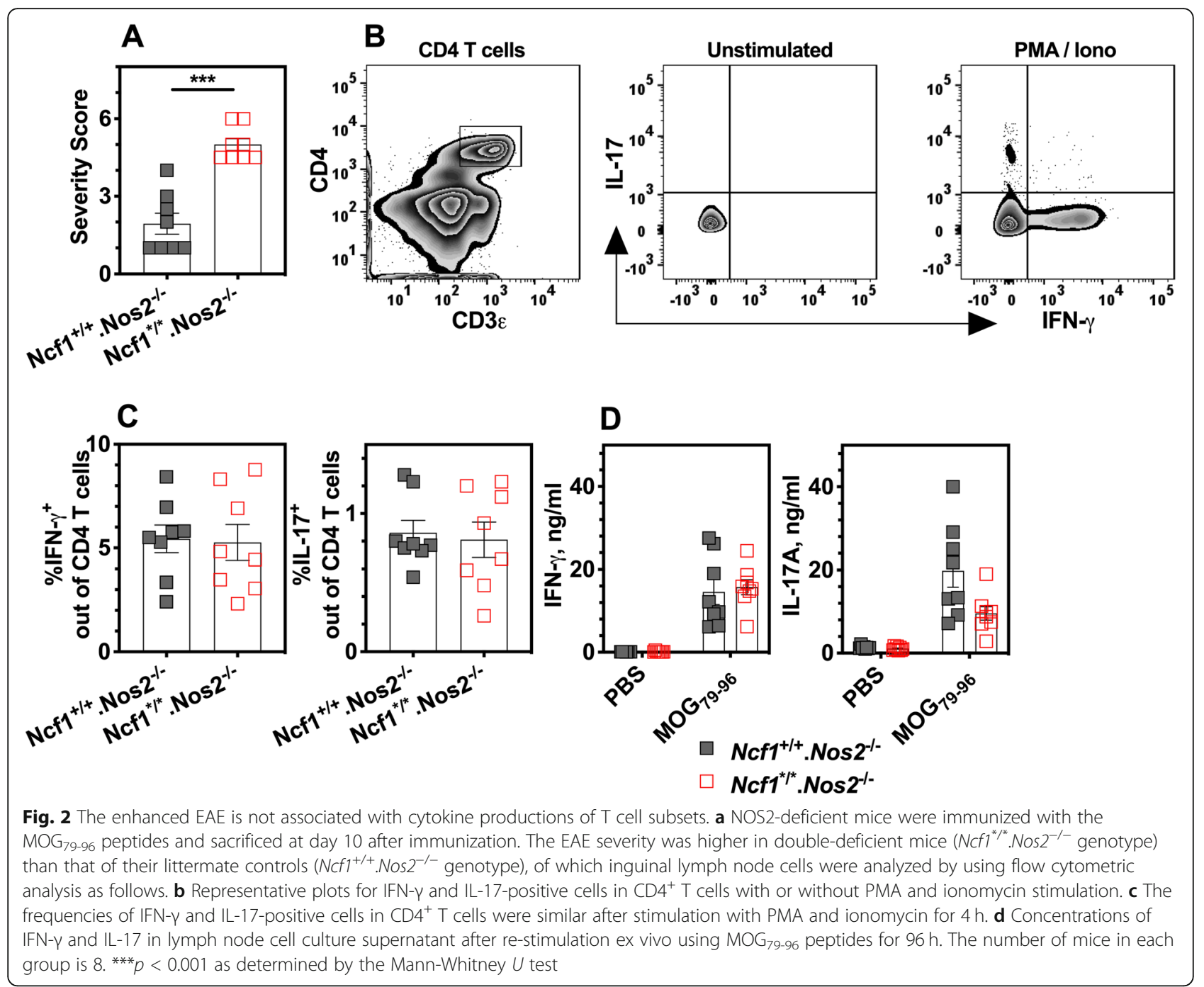

In summary, we did not find that NCF1-dependent effect on antigen-specific $\mathrm{T}$ cells responses during the early and peak stages of EAE in NOS2 deficient mice.

\section{EAE induction is associated with oxidative burst of neutrophils}

To study redox mechanisms of EAE, we next examined innate immune responses to immunization. We focused on the myeloid subset responsible for oxidative burst prior to EAE clinical onset. A previous study showed that upon PMA stimulation, there was no difference in NCF1 expression and oxidation burst of T cells between naïve NCF1 wild-type (B10Q.Ncf1 $1^{++}$) mice and NCF1deficient (B10Q.Ncf1 $\left.{ }^{* / *}\right)$ littermates, and antigen-specific $\mathrm{T}$-cell activation was controlled by oxidative signaling from macrophages [27]. Myeloid cells including neutrophils and monocytes/macrophages, typically expressing both NCF1 and NOS2, were recently shown to be important in the regulation of EAE at the induction phase by releasing IL-1 $\beta$ [31].

In the EAE model, we first measured the intracellular oxidative status in splenic myeloid cells and $\mathrm{T}$ cells from mice $\left(\mathrm{Ncf1}^{+/+} . \mathrm{Nos}^{+/+}\right.$and $\mathrm{Ncf1} 1^{* / *} . \mathrm{Nos}^{+/+}$genotypes) at day 4 post-immunization, using fluorescent dyes DHR and DCF by flow cytometric analysis [32], as shown in Fig. 3a and Additional file 3 and 4. DHR was used to detect peroxynitrite oxidation, and DCF was used for detecting hydrogen peroxide. Upon re-stimulation ex vivo with PMA, we found that NCF1 deficiency resulted in a higher frequency of splenic neutrophils. We observed that a little or no oxidative burst from NCF1-deficient myeloid cells upon PMA or PMA/ionomycin stimulation (Fig. 3b and Additional file 3), whereas expression of both NCF1 and NOS2 in neutrophils was shown in Fig. $3 c$ as evidence. There was also a very low level of oxidative burst from CD4 $\mathrm{T}$ cells, even though an elevated level was detected post stimulation, irrespective of NCF1 

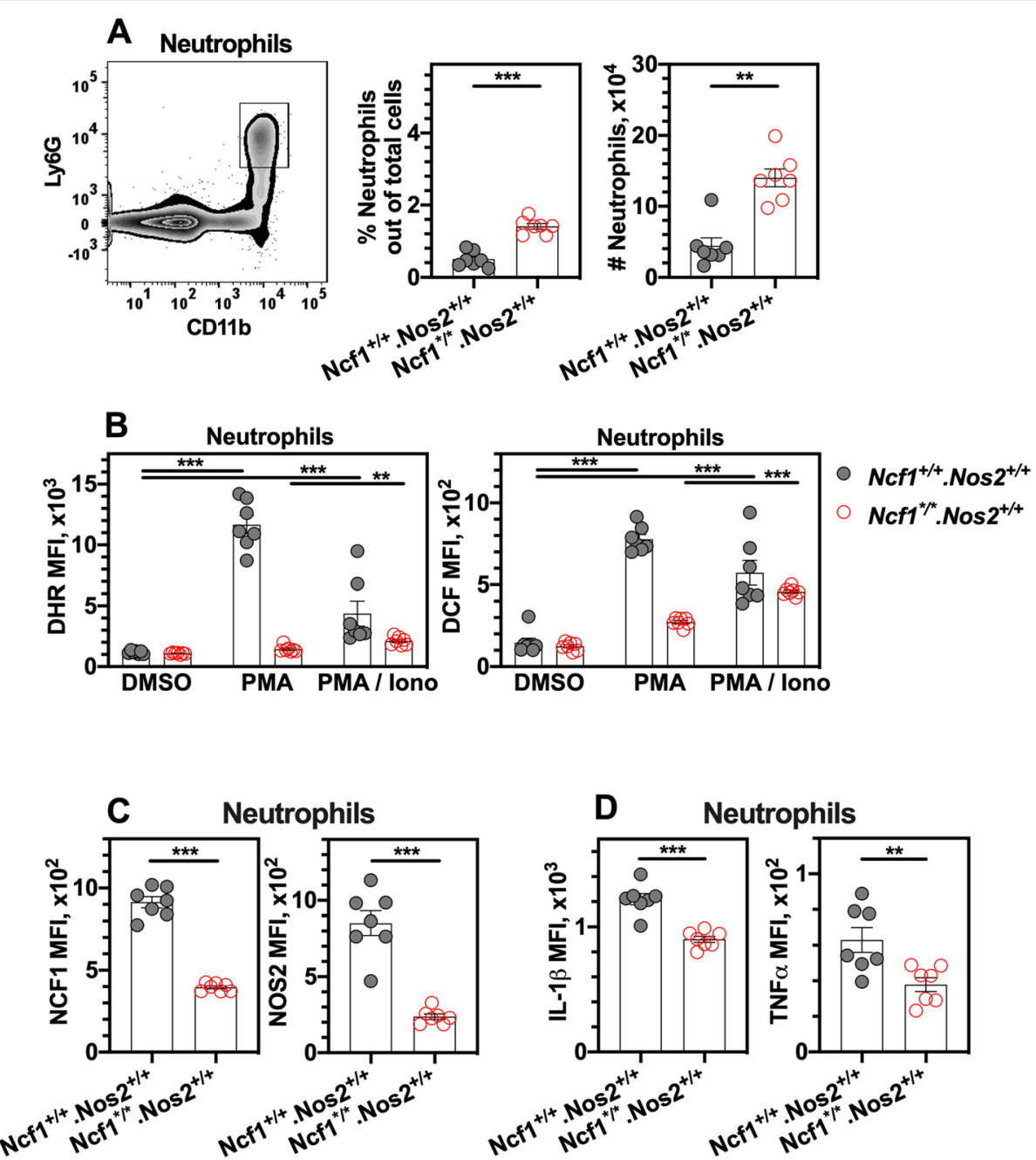

Fig. 3 NCF1 deficiency reduces IL-1 $\beta$ release from neutrophils in spleens prior to clinical onset. a Representative flow cytometry plot for neutrophils in the spleen. The solenocytes were collected from NCF1-deficient ( $\mathrm{NCF}^{* / *}$. Nos $2^{+/+}$genotype) and NCF1-sufficient mice $\left(\mathrm{NCF}^{+/+}\right.$.Nos2 ${ }^{+/+}$genotype) at day 4 post immunization. The frequency and cell number of neutrophils in the spleen are shown, upon stimulation with PMA. b Mean florescence intensities (MFIs) of DHR and DCF staining in neutrophils are shown, after cells were incubated ex vivo with PMA, PMA and ionomycin, or DMSO as the control. c MFIs of NCF1 and NOS2 staining in neutrophils are shown. $\mathbf{d}$ MFIs of IL-1 $\beta$ and TNF-a staining in neutrophils are shown. The number of mice is 7 per group. ${ }^{* *} p<0.01$ and ${ }^{* *} p<0.001$ as determined by the Mann-Whitney $U$ test

expression (Additional file 4). Therefore, it suggests that NCF1-derived oxidative burst is not the main source of oxidative signals in CD4 T cells. Additionally, flow cytometry analyses allow us to determine the level of cytokine production of myeloid cells, such as IL-1 $\beta$ and tumor necrosis factor- $\alpha$ (TNF- $\alpha$ ). NCF1 deficiency led to lower levels of pro-IL-1 $\beta$ and TNF- $\alpha$ in neutrophils (Fig. 3d), but not Ly6C $\mathrm{C}^{\text {hi }}$ monocytes (Additional file 3).

We finally used NCF1 and NOS2 double-deficient mice to further study redox regulation of innate immune responses to immunization. On basis of the above observations of reduced IL-1 $\beta$ and TNF- $\alpha$ in NCF1-deficient neutrophils, we conducted similar experiments with flow cytometry analysis of spleen cells in $N c f 1^{\prime \prime / *} . N o s 2^{-/-}$, $\mathrm{Ncf1}^{+/+} . \mathrm{Nos}_{2}{ }^{-/-}$, and wild-type mice $\left(\mathrm{Ncfl}^{+/+} . \mathrm{Nos}^{+/+}\right)$at day 4 post-immunization. Similar to the previous results in NOS2-sufficient mice (Fig. 3a), NCF1 deficiency led to an increased frequency of neutrophils in the spleen $\left(C D 11 b^{+}\right.$Ly6C ${ }^{\text {mid }}$, Fig. 4a, b), upon re-stimulation ex vivo with PMA. Importantly, an increased pro-IL-1 $\beta$ expression was shown in NCF1-deficient neutrophils (Fig. 4c), but not found in Ly6 $\mathrm{C}^{\text {hi }}$ monocytes and $\mathrm{Ly} 6 \mathrm{C}^{-}$myeloid cells (Additional file 5). In addition, since GM-CSFpositive $\mathrm{T}$ cell response could be regulated by neutrophils, we studied the immune responses against MOG $_{79-96}$ peptides by using a recall antigen assay to understand oxidative signaling. The splenic cells were re-stimulated with $\mathrm{MOG}_{79-96}$ peptides for $24 \mathrm{~h}$, and cell culture supernatants were analyzed. Neither IL- $1 \alpha$ nor GM-CSF was upregulated in the cell culture 


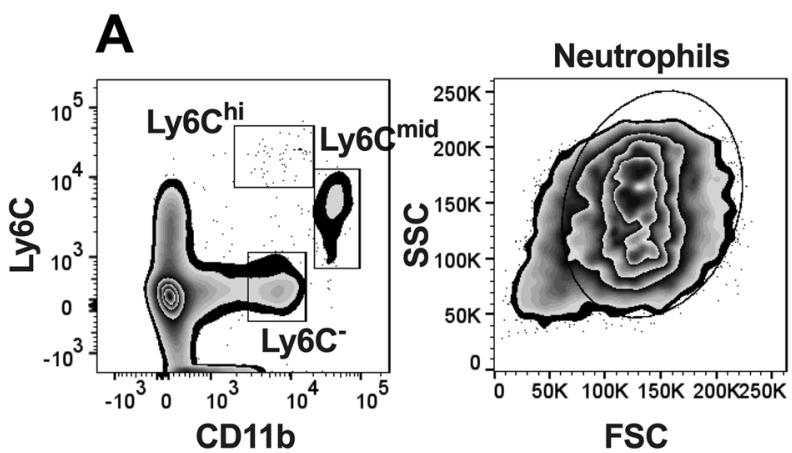

\section{B}
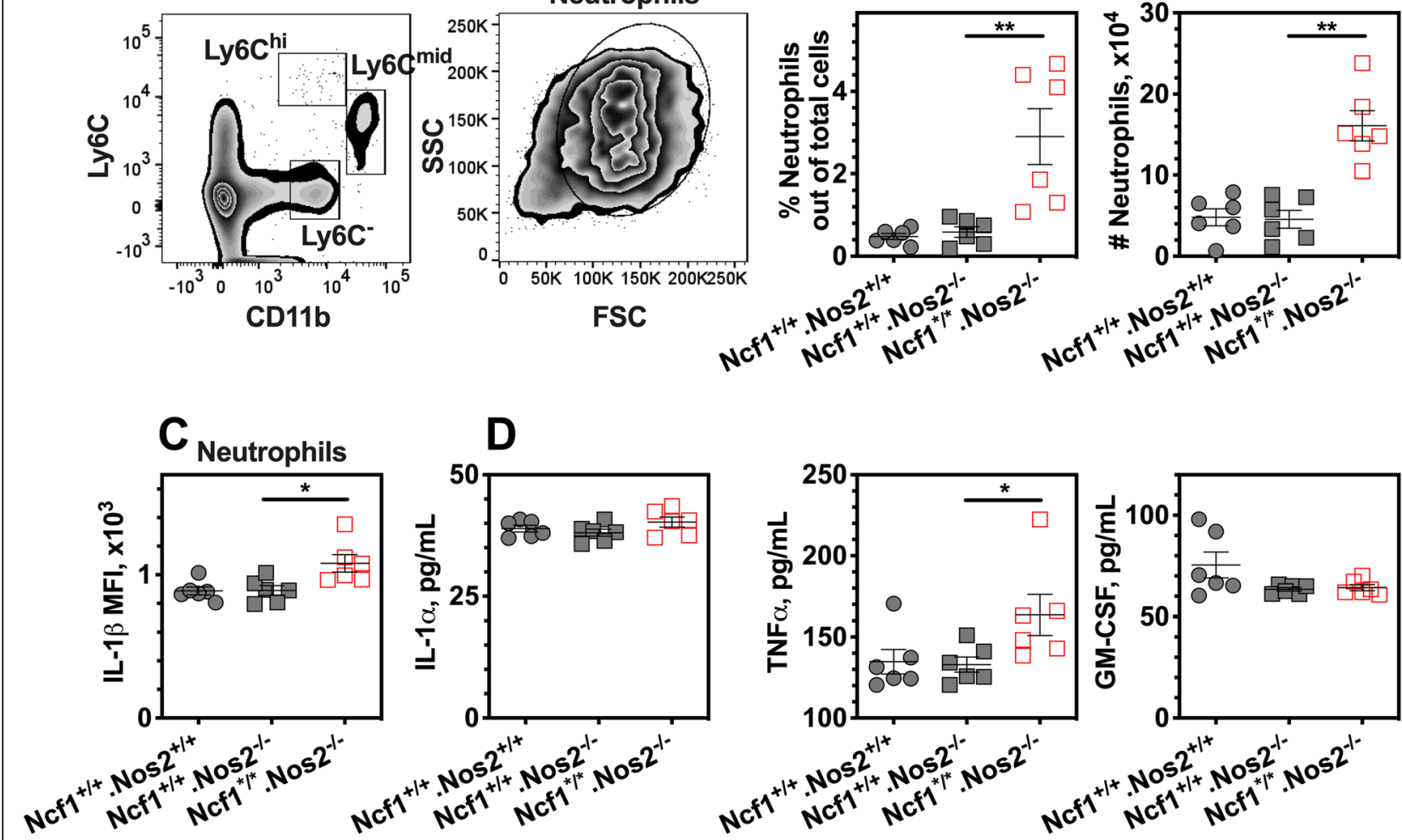

Fig. 4 Double deficiencies of NCF1 and NOS2 increase IL-1 $\beta$ release from neutrophils in the spleen prior to clinical onset. a Representative flow cytometry plots for neutrophils in the spleen. The splenocytes were collected from double-deficient mice (Ncf1 ${ }^{* *}$. Nos $2^{-/-}$genotype) and their

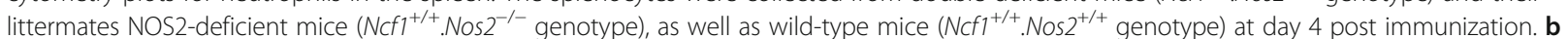
The frequency and cell number of neutrophils in the spleen are shown, upon stimulation with PMA. $\mathbf{c}$ The MFIs of IL-1 $\beta$ staining in splenic neutrophils are shown. $\mathbf{d}$ The cytokine levels of spleen cell culture supernatants were determined after incubation with MOG $_{79-96}$ Peptides for 24 h. The number of mice per group is $6 .{ }^{*} p<0.05$ and ${ }^{* *} p<0.01$ as determined by the Mann-Whitney $U$ test

supernatants from double-deficient cells. Nevertheless, double deficiencies in NCF1 and NOS2 resulted in an increased TNF- $\alpha$ production in the recall antigen assay (Fig. 4d).

In summary, we conclude that the number of neutrophils in the spleen and their IL- $1 \beta$ secretions are most closely associated with oxidative signaling in control of EAE induction.

\section{Discussion}

The oxidative burst derived by the NCF1-NOX2 complex could play a dual role in autoimmune disease. In NOS2-sufficient mice, we show that NCF1-dependent oxidative burst played a pathogenic role during peptideinduced EAE; however, based on NOS2-deficient mice, we find that NCF1-dependent oxidative burst was protective in EAE induction. The inter-dependent effects of NCF1 and NOS2 were associated with neutrophils rather than $\mathrm{T}$ cells in immune responses to immunization.

A promising concept to explain differences in EAE susceptibility is the regulation of IL- $1 \beta$ release by neutrophil-derived oxidative burst. The oxidative mechanisms underlaying transcription of the gene encoding the IL-1 $\beta$ precursor pro-IL-1 $\beta$, pro-IL-1 $\beta$ processing, and IL-1 $\beta$ cellular export are not understood well yet. IL- $1 \beta$ transcription can be induced by pertussis toxin at the time of immunization, and increased recruitment of pro-IL-1 $\beta$-producing neutrophils from the bone marrow to draining lymph nodes and the spleen was required for EAE induction [33-35]. Interestingly, the peak number of blood-derived neutrophils infiltrated into the brain of C57/BL6 mice was on day 4 post injection of pertussis toxin alone [33]. Neutrophil depletion using the 1A8 monoclonal antibody delayed the onset of EAE and attenuated clinical symptoms [36], and a similar effect was observed in C57/BL6 mice deficient in inflammasome genes (e.g., caspase- $1^{-/}$and $G s d m D^{-/-}$) involved in the processing of pro-IL-1 $\beta$ to active secreted IL-1 $\beta[37,38]$. $I L-1 \beta^{-/}$mice displayed the reduced EAE and also failed to remyelinate properly involved with the function of microglia or macrophages [39] and NOS2 [40]. In addition, NOX2-deficient mice exhibited an attenuation 
of EAE-induced IL-1 $\beta$ transcription in the brain at the day 20 post-immunization [41]. In this paper, we furthered the studies of neutrophil-dependent regulation of EAE development in the mouse model. We observed that NCF1 deficiency resulted in an increased number of neutrophils in the spleen. NCF1-deficient neutrophils produced less both IL- $1 \beta$ and TNF- $\alpha$, associated with delayed disease onset and reduced severity of EAE. Of interest, our results show that double-deficient mice in NCF1 and NOS2 exhibited an increase pro-IL-1 $\beta$ expression in neutrophils and a rapid development of enhanced EAE. Moreover, we did not find a similar increase in monocyte-limited pro-IL-1 $\beta$ expression in double-deficient mice, and our results are different from the published data that the periphery monocyte was the key to drive EAE by releasing IL-1 $\beta$ [42].

A possible explanation could be that the cytotoxicity of oxidative burst via peroxynitrite could modulate IL17-production of $\mathrm{CD} 4 \mathrm{~T}$ cells. It is a classical phenotype that RORyt and IL-17-expressing CD4 $\mathrm{T}$ cells transfer EAE to the naïve hosts [43]. A molecular mechanism for encephalitogenic IL-17 production is the intrinsic posttranslational modification of ROR $\gamma \mathrm{t}$ by peroxynitrite [24]. The $T$ cell endogenous peroxynitrite is a natural product at the interaction between NCF1 and NOS2 [24]. Peroxynitrite can be generated by surrounding cells in short-range and long-range mechanisms. By using an autocrine manner, $\mathrm{T}$ cells could produce superoxide likely by the NCF1-NOX2 complex [44, 45] and mitochondria [46] and NO by the NOS. Antigen-specific T cells can be also exposed to oxidative burst provided by monocytes/macrophages [27, 47] and endothelial cells [48] in a paracrine manner. In this study, we observed that the MFI of DHR staining in CD4 T cells was near to the background value, which was 10 times less than in splenic neutrophils and monocytes from the mice after immunization with $\mathrm{MOG}_{79-96}$ peptides. Although we showed a weak production of superoxide and $\mathrm{H}_{2} \mathrm{O}_{2}$ in $\mathrm{CD} 4 \mathrm{~T}$ cells induced by ionomycin together with PMA, it was clearly independent of NOX2 activity as evidenced by a similar MFI of DCF staining in NCF1 deficient cells. Moreover, we found little or no measurable expression of NCF1 and NOS2 in CD4 T cells from $\mathrm{MOG}_{79-96}$ peptides immunized mice. We detected a similar level of IL-17 in primed CD4 T cells from NOS2-deficient mice, regardless of NCF1 expression. Therefore, our results suggest that the neutrophildependent mechanism underlying enhanced EAE in double-deficient mice should be different from peroxynitrite-IL-17 producing T cell pathways.

Other mechanisms regulated the EAE induction could be TNF- $\alpha$ and GM-CSF pathways mediated by neutrophils. A GM-CSF-dependent signaling has shown that IFN- $\gamma$-deficient $\mathrm{T}$ cells can induce neutrophil-rich

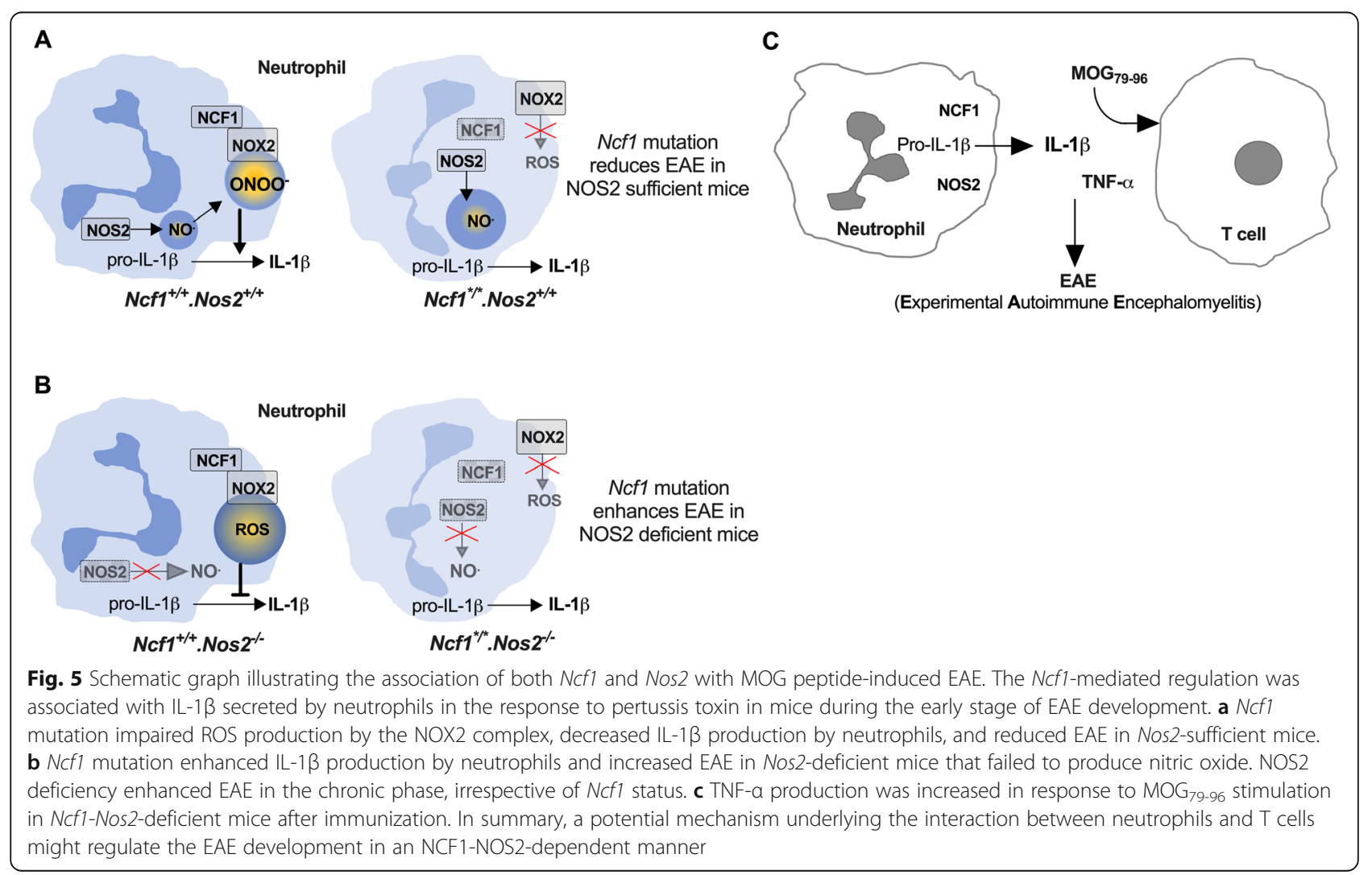


infiltrates and transfer EAE to the naïve host irrespective IL-17 signaling [49], and it has also been recently shown dispensable for disease induction [50]. TNF-deficient mice showed reduced EAE during the early stage but exacerbated disease during the chronic stage due to prolonged retention of $\mathrm{T}$ cells in the secondary lymphoid organs [51]. TNF- $\alpha$ ablation in monocytes/macrophages delayed the onset of EAE in challenged animals [52]. An interesting evidence by studies with humanized mice indicates that the soluble TNF- $\alpha$ signaling provided a protective effect on EAE induction through TNFR2 on the $\mathrm{CD}^{+} \mathrm{FOXP}^{+}$cells in the spleen, but not $\mathrm{T}$ cells in the CNS [53]. Our earlier data also showed that CTLA-4 deletion in adult mice resulted in an increase of $\mathrm{CD}^{+}{ }^{+} \mathrm{FOXP} 3^{+}$cells in the spleen and lymph nodes, leading to resistance to $\mathrm{MOG}_{79-96}$ peptide-induced EAE [54]. In the present study, we did not observe any difference on protein expression of GM-CSF from mice deficient in NCF1 and NOS2 during EAE induction, using a recall antigen assay of splenic and lymph node cells. Our data shows that NCF1 and NOS2 deficiencies resulted in an increase of TNF- $\alpha$ production, compared with the wildtype or NOS2-deficient group. Therefore, oxidative regulation will be an interesting follow-up study by assaying the function of TNF- $\alpha$-TNFR2 signaling on the $\mathrm{CD}^{+} \mathrm{FOXP3}^{+}$cells.

\section{Conclusion}

In conclusion, this study demonstrates that NCF1 and NOS2 can operate as a stand-alone or inter-dependent regulator, showing a dual role in the EAE model. The pathogenic effects of NCF1 on EAE induction were verified in NCF1-deficient mice and in wild-type mice with L-NAME treatments. The protective effect of NCF1 on EAE was shown in NOS2-deficient mice. NCF1-NOS2 double deficiency led to an increased number of neutrophils in the spleen and a higher release of IL-1 $\beta$ by neutrophils prior to clinical onset, followed by an exacerbated EAE. In addition, although NCF1 deficiency did not provide an added effect on IFN- $\gamma$ or IL-17 production of antigen-specific $\mathrm{T}$ cells during the early stage of EAE in NOS2-deficient mice, the double deficiencies resulted in an increased TNF- $\alpha$ production in the antigen recall assay. A potential mechanism underlying the interaction between neutrophils and $\mathrm{T}$ cells might regulate the EAE development in an NCF1-NOS2 dependent manner (Fig. 5).

\section{Supplementary information}

Supplementary information accompanies this paper at https://doi.org/10. 1186/s12974-020-01789-2.

Additional file 1: tiff format, title: NCF1 and NOS2 play a dual role in EAE. a, treatments of NOS inhibitor L-NAME suppress the induction of
EAE in wild type mice $\left(\mathrm{NcFl}^{+/+}\right.$.Nos2 $2^{+/+}$genotype). b, treatments of $\mathrm{L}$ NAME suppress the induction of EAE in NCF1-deficient mice $\left(\mathrm{NCfl}^{* / *}\right.$.Nos2 ${ }^{+/+}$genotype), but prevent the chronic remission. Weight restoration was a crucial component of EAE remission. In the absence of NCF1, L-NAME treatment led to a failure at weight restoration at the chronic stage. c, a prolonged EAE is shown due to NOS2 deficiency in wild type mice, accompanying with the failure of weight restoration after day 15 post immunization. d, NOS2 deficiency enhances EAE in NCF1 deficient mice. The number of mice that developed EAE and the total number of mice in each group are stated in brackets. ${ }^{*} p<0.05,{ }^{* *} p<0.01$, ${ }^{* * *} p<0.001$ and ${ }^{* * *} p<0.0001$ as determined by the Mann-Whitney $U$ test.

Additional file 2: tiff format, title: Double deficiencies do not result in any difference on IL-17 production in a recall assay of spleen cells, compared with NOS2 deficiency. a, before euthanasia, clinical scores of EAE were evaluated at day 14 post-immunization, among $\mathrm{Ncfl}^{+/+} . \mathrm{Nos}^{+/+}$ mice and their $\mathrm{NCFl}^{* / *}$. Nos2 ${ }^{+/+}$littermates, together with $\mathrm{NcFl}^{+/+} . \mathrm{Nos}^{2-/-}$ mice and their $\mathrm{NcFl}^{* / *}$.Nos2 $2^{-/-}$littermates. Spleens were isolated and used in the re-stimulation assay ex vivo. $\mathbf{b}$, the level of nitrite plus nitrate is measured as an indicator of $\mathrm{NO}$ production and, $\mathbf{c}, \mathrm{IL}-17$ concentration in the supernatant is characterized as a positive control in the T cell assay after stimulation using ConA for 96 h. d, IL-17 production in the supernatant was measured in the recall assay using MOG T9-96 peptides. The number of mice that developed EAE and the total number of mice are stated in brackets. ${ }^{*} p<0.05$ and ${ }^{* *} p<0.01$ as determined by the MannWhitney $\mathrm{U}$ test.

Additional file 3: tiff format, title: NCF1 deficiency has no effect on IL$1 \beta$ release from Ly6C ${ }^{\text {hi }}$ monocytes in the spleen prior to clinical onset. $\mathbf{a}$, a representative flow cytometry plot for $L y 6 C^{h i}$ monocytes in the spleen. The splenocytes were collected from NCF1 deficient $\left(\mathrm{NCFl}^{* / *}\right.$. Nos $\left.2^{+/+}\right)$and sufficient mice $\left(\mathrm{NCF}^{+/+}\right.$. Nos2 $\left.2^{+/+}\right)$at day 4 post immunization. The frequency and cell number of $\mathrm{Ly}_{6} \mathrm{C}^{\text {hi }}$ monocytes in the spleen are shown, upon stimulation with PMA. b, mean florescence intensities (MFIs) of DHR and DCF staining of Ly6C $C^{\text {hi }}$ monocytes are shown, after these cells were incubated ex vivo with PMA, PMA and ionomycin or DMSO as the control. c, the MFIs of IL-1 $\beta$ and TNF-a staining in Ly6Chi monocytes are shown. The number of mice is 7 per group. ${ }^{* *} p<0.01$ and ${ }^{* *} p<0.001$ as determined by the Mann-Whitney $U$ test.

Additional file 4: tiff format, title: There is little or no detectable NCF1 and NOS2 expression in CD4 T cells in the spleen prior to clinical onset. a, a representative flow cytometry plot for CD4 T cells in the spleen. The splenocytes were collected from NCF1 deficient $\left(\mathrm{NCfl}^{* / *} . \mathrm{Nos}_{2}{ }^{+/+}\right)$and sufficient mice $\left(\mathrm{NCfl}^{+/+} \cdot \mathrm{Nos}^{+/+}\right)$at day 4 post immunization. The frequency and cell number of CD4 T cells in the spleen are shown, upon stimulation with PMA. b, mean florescence intensities (MFIs) of DHR and DCF staining of CD4 T cells are shown, after these cells were incubated ex vivo with PMA, PMA and ionomycin or DMSO as the control. c, the MFIs of NCF1 and NOS2 staining in CD4 T cells are shown. The number of mice is 7 per group. ${ }^{* *} p<0.01$ and ${ }^{* * *} p<0.001$ as determined by the Mann-Whitney U test.

Additional file 5: tiff format, title: There is no detectable change of pro$\mathrm{IL}-1 \beta$ expression in Ly6 $\mathrm{C}^{\text {hi }}$ monocytes and Ly6C myeloid cells in the spleen prior to clinical onset. $\mathbf{a}$, here are the frequencies of $L y 6 C^{\text {hi }}$ monocytes and Ly6C myeloid cells stated in Fig. 4a, upon stimulation with PMA. b, the MFIs of IL-1 $\beta$ in selected subsets are shown. The number of mice per group is $6 .{ }^{* *} p<0.01$ as determined by the Mann-Whitney $U$ test.

\section{Abbreviations}

DCF: 6-Carboxy-2',7'-dichlorodihydrofluorescein diacetate; DHR: Dihydrorhodamine 123; EAE: Experimental autoimmune encephalomyelitis; GM-CSF: Granulocyte-macrophage colony-stimulating factor; IFN- $\gamma$ : Interferon-gamma; IL-1 $\beta$ : Interleukin 1 $\beta$; IL-17: Interleukin 17A; LNAME: NG-nitro-L-arginine methyl ester; NCF1: Neutrophil cytosol factor 1; NO: Nitric oxide; NOS: Nitric oxide synthase; NOS2: iNOS, inducible nitric oxide synthase; MOG: Myelin oligodendrocyte glycoprotein; MS: Multiple sclerosis; PMA: Phorbol 12-myristate 13-acetate; TNF-a: Tumor necrosis factor-a 


\section{Acknowledgements}

The authors thank Carlos Palestro and Kristina Palestro for excellent animal care.

\section{Authors' contributions}

JZ designed the research; performed the experiments, including acquiring data and analyzing data; and wrote and revised the manuscript. AY analyzed the data and revised the manuscript. $\mathrm{RH}$ designed the research, analyzed the data, and revised the manuscript. The authors read and approved the final manuscript.

\section{Funding}

This work was supported by grants from the Knut and Alice Wallenberg Foundation (KAW 2015.0063), the Swedish Association against Rheumatism (R-757331), the Swedish Research Council (2015-02662), and the Swedish Foundation for Strategic Research (RB13-0156). The research leading to these results received further funding from the European Union Innovative Medicine Initiative project BeTheCure (115142). Open access funding provided by Karolinska Institute.

\section{Availability of data and materials}

All data generated or analyzed during this study are included in this published article [and its supplementary information files].

\section{Ethics approval and consent to participate}

The animal study protocols were approved by the Stockholm regional animal ethics committee, Sweden (N83/13).

\section{Consent for publication}

Not applicable

\section{Competing interests}

The authors declare that they have no competing interests

\section{Author details}

${ }^{1}$ Medical Inflammation Research, Department of Medical Biochemistry and Biophysics, Karolinska Institute, 17177 Stockholm, Sweden. ${ }^{2}$ Beijing Advanced Innovation Center for Big Data-Based Precision Medicine, Beihang University, Beijing 100083, China.

\section{Received: 31 December 2019 Accepted: 26 March 2020}

Published online: 11 April 2020

\section{References}

1. Zhong J, Olsson LM, Urbonaviciute V, Yang M, Bäckdahl L, Holmdahl R. Association of NOX2 subunits genetic variants with autoimmune diseases. Free Radic Biol Med. 2018:125:72-80.

2. Sies H, Berndt C, Jones DP. Oxidative stress. Annu Rev Biochem. 2017;86: 715-48.

3. Olofsson P, Holmberg J, Tordsson J, Lu S, Åkerström B, Holmdahl R. Positional identification of $\mathrm{Ncf1}$ as a gene that regulates arthritis severity in rats. Nat Genet. 2003:33:25-32.

4. Hultqvist M, Sareila O, Vilhardt F, Norin U, Olsson LM, Olofsson P, et al. Positioning of a polymorphic quantitative trait nucleotide in the $\mathrm{Ncfl}$ gene controlling oxidative burst response and arthritis severity in rats. Antioxid Redox Signal. 2011;14:2373-83.

5. Hultqvist M, Olofsson P, Holmberg J, Backstrom BT, Tordsson J, Holmdahl R. Enhanced autoimmunity, arthritis, and encephalomyelitis in mice with a reduced oxidative burst due to a mutation in the $\mathrm{Ncf1}$ gene. Proc Natl Acad Sci. 2004;101:12646-51.

6. Kelkka T, Kienhöfer D, Hoffmann M, Linja M, Wing K, Sareila O, et al. Reactive oxygen species deficiency induces autoimmunity with type 1 interferon signature. Antioxid Redox Signal. 2014;21:2231-45.

7. Olsson LM, Nerstedt A, Lindqvist A-K, Johansson ÅCM, Medstrand P, Olofsson $\mathrm{P}$, et al. Copy number variation of the gene NCF1 is associated with rheumatoid arthritis. Antioxid Redox Signal. 2012;16:71-8.

8. Olsson LM, Johansson ÅC, Gullstrand B, Jönsen A, Saevarsdottir S, Rönnblom $L$, et al. A single nucleotide polymorphism in the NCF1 gene leading to reduced oxidative burst is associated with systemic lupus erythematosus. Ann Rheum Dis. 2017;76:1607-13.
9. Zhao J, Ma J, Deng Y, Kelly JA, Kim K, Bang S-Y, et al. A missense variant in NCF1 is associated with susceptibility to multiple autoimmune diseases. Nat Genet. 2017:49:433-7.

10. Linge P, Arve S, Olsson LM, Leonard D, Sjöwall C, Frodlund M, et al. NCF1339 polymorphism is associated with altered formation of neutrophil extracellular traps, high serum interferon activity and antiphospholipid syndrome in systemic lupus erythematosus. Ann Rheum Dis. 2019; annrheumdis-2019-215820.

11. Bergsteinsdottir $\mathrm{K}$, Yang H-T, Pettersson U, Holmdahl R. Evidence for common autoimmune disease genes controlling onset, severity, and chronicity based on experimental models for multiple sclerosis and rheumatoid arthritis. J Immunol. 2000;164:1564-8.

12. Becanovic K, Jagodic M, Sheng JR, Dahlman I, Aboul-Enein F, Wallstrom E, et al. Advanced intercross line mapping of Eaes reveals Ncf-1 and CLDN4 as candidate genes for experimental autoimmune encephalomyelitis. Immunol. 2006;176:6055-64.

13. van der Veen RC, Dietlin TA, Hofman FM, Pen L, Segal BH, Holland SM. Superoxide prevents nitric oxide-mediated suppression of helper $\mathrm{T}$ lymphocytes: decreased autoimmune encephalomyelitis in nicotinamide adenine dinucleotide phosphate oxidase knockout mice. J Immunol. 2000; 164:5177-83.

14. Allan ERO, Tailor P, Balce DR, Pirzadeh P, McKenna NT, Renaux B, et al. NADPH Oxidase modifies patterns of MHC class II-restricted epitopic repertoires through redox control of antigen processing. J Immunol. 2014; 192:4989-5001.

15. Warnecke A, Musunuri S, N'diaye M, Sandalova T, Achour A, Bergquist J, et al. Nitration of MOG diminishes its encephalitogenicity depending on MHC haplotype. J Neuroimmunol. 2017;303:1-12.

16. Mattila JT, Thomas AC. Nitric oxide synthase: non-canonical expression patterns. Front Immunol. 2014:5:478.

17. Li S, Vana AC, Ribeiro R, Zhang Y. Distinct role of nitric oxide and peroxynitrite in mediating oligodendrocyte toxicity in culture and in experimental autoimmune encephalomyelitis. Neuroscience. 2011;184:107-19.

18. Sahrbacher UC, Lechner F, Eugster HP, Frei K, Lassmann H, Fontana A. Mice with an inactivation of the inducible nitric oxide synthase gene are susceptible to experimental autoimmune encephalomyelitis. Eur J Immunol. 1998;28:1332-8

19. Hooper DC, Bagasra O, Marini JC, Zborek A, Ohnishi ST, Kean R, et al. Prevention of experimental allergic encephalomyelitis by targeting nitric oxide and peroxynitrite: implications for the treatment of multiple sclerosis. Proc Natl Acad Sci. 1997:94:2528-33.

20. Cross AH, Misko TP, Lin RF, Hickey WF, Trotter JL, Tilton RG. Aminoguanidine, an inhibitor of inducible nitric oxide synthase, ameliorates experimental autoimmune encephalomyelitis in SJL mice. J Clin Invest. 1994:93:2684-90.

21. Fenyk-Melody JE, Garrison AE, Brunnert SR, Weidner JR, Shen F, Shelton BA, et al. Experimental autoimmune encephalomyelitis is exacerbated in mice lacking the NOS2 gene. J Immunol Baltim Md 1950. 1998;160:2940-6.

22. Zielasek J, Jung S, Gold R, Liew FY, Toyka KV, Hartung HP. Administration of nitric oxide synthase inhibitors in experimental autoimmune neuritis and experimental autoimmune encephalomyelitis. J Neuroimmunol. 1995;58:81-8.

23. Dalton DK, Wittmer S. Nitric-oxide-dependent and independent mechanisms of protection from CNS inflammation during Th1-mediated autoimmunity: evidence from EAE in iNOS KO mice. J Neuroimmunol. 2005; 160:110-21.

24. Yang J, Zhang R, Lu G, Shen Y, Peng L, Zhu C, et al. T cell-derived inducible nitric oxide synthase switches off TH17 cell differentiation. J Exp Med. 2013; 210:1447-62.

25. Niedbala W, Besnard A-G, Jiang HR, Alves-Filho JC, Fukada SY, Nascimento $D$, et al. Nitric oxide-induced regulatory T cells inhibit Th17 but not Th1 cell differentiation and function. J Immunol. 2013;191:164-70.

26. Abdul-Majid K-B, Jirholt J, Stadelmann C, Stefferl A, Kjellén P, Wallström E, et al. Screening of several $\mathrm{H}-2$ congenic mouse strains identified $\mathrm{H}-2 \mathrm{q}$ mice as highly susceptible to MOG-induced EAE with minimal adjuvant requirement. J Neuroimmunol. 2000;111:23-33.

27. Gelderman KA, Hultqvist M, Pizzolla A, Zhao M, Nandakumar KS, Mattsson R, et al. Macrophages suppress T cell responses and arthritis development in mice by producing reactive oxygen species. J Clin Invest. 2007:117:3020-8.

28. Laubach VE, Shesely EG, Smithies O, Sherman PA. Mice lacking inducible nitric oxide synthase are not resistant to lipopolysaccharide-induced death. Proc Natl Acad Sci U S A. 1995;92:10688-92. 
29. Zhong J, Scholz T, Yau ACY, Guerard S, Hüffmeier U, Burkhardt H, et al. Mannan-induced Nos2 in macrophages enhances IL-17-driven psoriatic arthritis by innate lymphocytes. Sci Adv. 2018;4:eaas9864.

30. Zhong J, Yau ACY, Holmdahl R. Regulation of $T$ cell function by reactive nitrogen and oxygen species in collagen-induced arthritis. Antioxid Redox Signal. 2020;32:161-72

31. Jain A, Irizarry-Caro RA, McDaniel MM, Chawla AS, Carroll KR, Overcast GR, et al. T cells instruct myeloid cells to produce inflammasome-independent IL-1 $\beta$ and cause autoimmunity. Nat Immunol. 2020;21:65-74.

32. Kalyanaraman B, Darley-Usmar V, Davies KJA, Dennery PA, Forman HJ, Grisham MB, et al. Measuring reactive oxygen and nitrogen species with fluorescent probes: challenges and limitations. Free Radic Biol Med. 2012;52:1-6.

33. Ronchi F, Basso C, Preite S, Reboldi A, Baumjohann D, Perlini L, et al. Experimental priming of encephalitogenic Th1/Th17 cells requires pertussis toxin-driven IL-1 $\beta$ production by myeloid cells. Nat Commun. 2016;7:11541.

34. Rumble JM, Huber AK, Krishnamoorthy G, Srinivasan A, Giles DA, Zhang X, et al. Neutrophil-related factors as biomarkers in EAE and MS. J Exp Med. 2015;212:23-35.

35. Yan Z, Yang W, Parkitny L, Gibson SA, Lee KS, Collins F, et al. Deficiency of Socs3 leads to brain-targeted experimental autoimmune encephalomyelitis via enhanced neutrophil activation and ROS production. JCI Insight. 2019;4: e126520.

36. Aubé B, Lévesque SA, Paré A, Chamma É, Kébir H, Gorina R, et al. Neutrophils mediate blood-spinal cord barrier disruption in demyelinating neuroinflammatory diseases. J Immunol. 2014;193:2438-54.

37. Furlan R, Martino G, Galbiati F, Poliani PL, Smiroldo S, Bergami A, et al. Caspase-1 regulates the inflammatory process leading to autoimmune demyelination. J Immunol Baltim Md 1950. 1999;163:2403-9.

38. Li S, Wu Y, Yang D, Wu C, Ma C, Liu X, et al. Gasdermin D in peripheral myeloid cells drives neuroinflammation in experimental autoimmune encephalomyelitis. J Exp Med. 2019;216:2562-81.

39. Mason JL, Suzuki K, Chaplin DD, Matsushima GK. Interleukin-1 beta promotes repair of the CNS. J Neurosci Off J Soc Neurosci. 2001;21:7046-52.

40. Mishra BB, Rathinam VAK, Martens GW, Martinot AJ, Kornfeld H, Fitzgerald $K A$, et al. Nitric oxide controls the immunopathology of tuberculosis by inhibiting NLRP3 inflammasome-dependent processing of IL-1 $\beta$. Nat Immunol. 2013;14:52-60.

41. Ravelli KG, Santos GD, Dos Santos NB, Munhoz CD, Azzi-Nogueira D, Campos AC, et al. Nox2-dependent neuroinflammation in an EAE model of multiple sclerosis. Transl Neurosci. 2019;10:1-9.

42. Paré $A$, Mailhot $B$, Lévesque SA, Juzwik $C$, Ignatius Arokia Doss PM, Lécuyer $M-A$, et al. IL-1 $\beta$ enables CNS access to CCR2 hi monocytes and the generation of pathogenic cells through GM-CSF released by CNS endothelial cells. Proc Natl Acad Sci. 2018;115:E1194-E1203.

43. Grifka-Walk HM, Lalor SJ, Segal BM. Highly polarized Th17 cells induce EAE via a T-bet independent mechanism. Eur J Immunol. 2013;43:2824-31.

44. Jackson SH, Devadas S, Kwon J, Pinto LA, Williams MS. T cells express a phagocyte-type NADPH oxidase that is activated after T cell receptor stimulation. Nat Immunol. 2004:5:818-27.

45. Emmerson A, Trevelin SC, Mongue-Din H, Becker PD, Ortiz C, Smyth LA, et al. Nox2 in regulatory T cells promotes angiotensin II-induced cardiovascular remodeling. J Clin Invest. 2018;128:3088-101.

46. Sena LA, Li S, Jairaman A, Prakriya M, Ezponda T, Hildeman DA, et al. Mitochondria are required for antigen-specific $T$ cell activation through reactive oxygen species signaling. Immunity. 2013;38:225-36.

47. Carlström KE, Ewing E, Granqvist M, Gyllenberg A, Aeinehband S, Enoksson SL, et al. Therapeutic efficacy of dimethyl fumarate in relapsing-remitting multiple sclerosis associates with ROS pathway in monocytes. Nat Commun. 2019;10:3081.

48. Huppert J, Closhen D, Croxford A, White R, Kulig P, Pietrowski E, et al. Cellular mechanisms of IL-17-induced blood-brain barrier disruption. FASEB J. 2010;24:1023-34.

49. Kroenke MA, Chensue SW, Segal BM. EAE mediated by a non-IFN- $\gamma /$ non-IL17 pathway. Eur J Immunol. 2010;40:2340-8.

50. Duncker PC, Stoolman JS, Huber AK, Segal BM. GM-CSF promotes chronic disability in experimental autoimmune encephalomyelitis by altering the composition of central nervous system-infiltrating cells, but is dispensable for disease induction. J Immunol. 2018;200:966-73.

51. Kruglov AA, Lampropoulou V, Fillatreau S, Nedospasov SA. Pathogenic and protective functions of TNF in neuroinflammation are defined by its expression in T lymphocytes and myeloid cells. J Immunol. 2011;187: 5660-70.

52. Wolf $\mathrm{Y}$, Shemer A, Polonsky M, Gross M, Mildner A, Yona S, et al. Autonomous TNF is critical for in vivo monocyte survival in steady state and inflammation. J Exp Med. 2017;214:905-17.

53. Atretkhany K-SN, Mufazalov IA, Dunst J, Kuchmiy A, Gogoleva VS, Andruszewski $D$, et al. Intrinsic TNFR2 signaling in T regulatory cells provides protection in CNS autoimmunity. Proc Natl Acad Sci U S A. 2018;115:13051-6.

54. Klocke K, Sakaguchi S, Holmdahl R, Wing K. Induction of autoimmune disease by deletion of CTLA-4 in mice in adulthood. Proc Natl Acad Sci U S A. 2016;113:E2383-92.

\section{Publisher's Note}

Springer Nature remains neutral with regard to jurisdictional claims in published maps and institutional affiliations.
Ready to submit your research? Choose BMC and benefit from:

- fast, convenient online submission

- thorough peer review by experienced researchers in your field

- rapid publication on acceptance

- support for research data, including large and complex data types

- gold Open Access which fosters wider collaboration and increased citations

- maximum visibility for your research: over $100 \mathrm{M}$ website views per year

At BMC, research is always in progress.

Learn more biomedcentral.com/submissions 